\title{
Corporate Policies of the Nuclear Vendors
}

\author{
Stephen D. Thomas ${ }^{1}$
}

\section{Abstract}

The nuclear reactor supply industry, once seen as an essential component of diversified companies with an electrical engineering capability, is now seen in Europe, USA and Japan as a risky niche business for specialist companies. Vendors from Russia and China now appear likely to win the vast majority of new reactor orders although in both cases, their technologies have not been reviewed by experienced Western regulators. Russia may not have the financial strength to back up its large order book while China has yet to win orders in open export markets.

1 Stephen Thomas, University of Greenwich, United Kingdom, stephen.thomas@greenwich. ac.uk

(C) The Author(s) 2019

R. Haas et al. (Eds.), The Technological and Economic Future

of Nuclear Power, Energiepolitik und Klimaschutz. Energy Policy 


\section{Introduction}

When nuclear power began to be commercially exploited in the 1950s, it was seen by the major 'national champion' diversified engineering companies as the technology of the future and therefore a key capability to acquire. In the USA, such companies included Westinghouse and GE, in Germany Siemens and AEG, in Japan Hitachi, Mitsubishi and Toshiba and in France Compagnie General d'Electricité (CGE) and Empain Schneider. Russia also developed its own technologies but it had little impact outside the Soviet Republics and the Comecon countries until the collapse of the Soviet Union in 1990. China has only become a force in nuclear markets since 2008, while, for various reasons, India, despite pursuing nuclear power since the 1960s has not built a competitive nuclear reactor supply industry.

By 2018, the picture was very different to that of the 1950s. Nuclear power had consistently failed to meet expectations and was increasingly seen as a technology that was not central to corporate ambitions. Westinghouse had sold its nuclear division to the British government in 1999 who sold it on to Toshiba in 2006; GE effectively exited the business in 2006 leaving it largely in the hands of its Japanese collaborator, Hitachi; Siemens exited the sector in 2009; AEG collapsed in the mid70s; Mitsubishi had made little impact outside Japan; the French companies had been reorganised several times. The sector has generally not been profitable and by 2016, Areva, the latest incarnation of the French nuclear industry was effectively bankrupt after six consecutive years of losses and was split up with a majority stake in its reactor division being bought by the French utility, EDF, reverting to its previous name, Framatome. Westinghouse declared bankruptcy in March 2017 and was sold by Toshiba to a Canadian company, Brookfield Business Partners. However, there were major players both integrally connected to their national government. Russia's champion was the massive Rosatom group which, through a huge number of subsidiaries, contained the whole range of nuclear activities including fuel cycle, reactor sales, and reactor ownership and operation. China had three vendors all with a wide range of nuclear activities, attempting to make an impression on the international market: China General Nuclear (CGN), China National Nuclear Power Corporation (CNNC) and the SNPTC division of State Power Investment Corporation (SPI). Korea emerged as a potential reactor exporter in 2010 through Korea Hydro Nuclear Power Co (KHNPC) winning an order for four reactors to the United Arab Emirates. By 2018, it had not won further export orders and it remains to be seen whether it can compete with the stronger, better established vendors.

Other vendors include, Atomic Energy of Canada Limited (AECL), Mitsubishi and The Nuclear Power Corporation of India Ltd (NPCIL). However, their prospects for exports appear limited and they are not examined further 
In this chapter, we examine the strategies of the seven established reactor vendors: Framatome, Rosatom, Hitachi-GE, Toshiba/Westinghouse, CGN, CNNC and SPI. We look at their strengths and weaknesses including:

- Experience with their current technologies;

- Their home market;

- Their target export markets;

- Their ability to offer financing to their prospective customers.

\section{The historical structure}

The main pioneers of the technology were two US companies, Westinghouse and GE offering light water cooled and moderated reactors developed from submarine propulsion reactors. Westinghouse developed the Pressurised Water Reactor (PWR) while GE developed the Boiling Water Reactor (BWR). Japan and Germany tried to develop their own technologies but with limited success and their main effort went into licensing and indigenising these US technologies. The companies took licenses with their long-term partners in the heavy electrical industry, Mitsubishi and Siemens with Westinghouse and Hitachi, Toshiba and AEG with GE. France followed its own technological route until 1969 when it too adopted US technology, Empain Schneider licensing the PWR from Westinghouse and CGE, the BWR from GE.

The exceptions to this pattern of licensing US were the UK and Canada. The UK tried to develop its own technologies (gas-cooled, graphite moderated reactors) until 1977 when it adopted the Westinghouse PWR. Unlike the other countries, the major companies in the UK, like GEC never put their weight behind the nuclear programme preferring to take stakes in weak consortia that frequently failed. By the time the PWR was adopted, it was too late for UK companies to develop a distinctive capability. Canada developed heavy water cooled and moderated reactors, Candu, for its home market and it has exported these to Argentina, China, Korea, Romania, India and Pakistan. A particular attraction for some buyers was that unlike PWRs and BWRs, this design did not need enriched Uranium. Enrichment is a technology with military sensitivity and is controlled mainly by USA, Russia, UK and France and using PWRs or BWRs inevitably involves some degree of dependence on these countries. However, the technology AECL is offering is old and appears to have very few prospects of new orders. 


\section{The vendors}

\section{Toshiba}

Toshiba's roots in the nuclear business go back to the 1960s and its participation in Japan's Boiling Water Reactor (BWR) programme. Japan's electricity system is split into two parts with all equipment for the northern half, including Tokyo Electric, supplied by Toshiba and Hitachi using designs licensed from GE. This pattern continued with nuclear power. Japan's first BWRs were imported, then orders were split reasonably evenly between Hitachi and Toshiba with, typically, one of the companies the primary contractor for the nuclear steam supply system (NSSS) and the other supplying the other high value item, the turbine generator. The US market collapsed in the mid-70s and Hitachi and Toshiba took a more central role in new reactor design development, notably with the Advance Boiling Water Reactor (ABWR) announced in 1980 and with its first order in 1986. An important exception was the development of the Economic Simplified Boiling Water Reactor (ESBWR) announced in 2000, which was very much a product for the US market and has not been seriously considered for Japan.

Toshiba and Hitachi never played a lead role in exports of the BWR with, for example, the most recent BWR export, for Taiwan, going to GE. Whether this was a conscious decision by the Japanese companies not to pursue exports or due to restrictions imposed by their licensor, GE, is not easy to determine. However, other technology licensees such as Siemens and Framatome chose to end their license agreements, in 1975 and 1982 respectively, when they felt they did not need the support of their licensor.

This arrangement between Hitachi, Toshiba and GE ended in 2006 when Toshiba chose to buy the Westinghouse reactor division, outbidding its rivals Mitsubishi and Hitachi. The Westinghouse nuclear division had been bought by the UK government in 1999 via its fuel cycle company, British Nuclear Fuels Limited (BNFL) for \$1.1bn. BNFL subsequently bought ABB's and Combustion Engineering's nuclear business for $\$ 485 \mathrm{~m}^{2}$. The government planned to privatise BNFL and presumably create a reactor vendor business. These plans were destroyed by the effective financial collapse of BNFL in 2002 and the subsequent break-up of BNFL's assets including the sale of a 77 per cent stake in the Westinghouse/ABB/Combustion Engineering group to Toshiba in 2006 for $\$ 4.16 \mathrm{bn}^{3}$. Inevitably, this led to the breaking of the

2 The Times 'BNFL makes Pounds 300m US acquisition' December 30, 1999

3 The Shaw Group took a 20 per cent stake and Ishikawajima-Harima Heavy Industries Co. purchased the remaining 3 per cent stake. Associated Press 'Toshiba completes acquisition of Westinghouse, U.S. atomic power plant company' October 17, 2006 
relationship between Toshiba and GE and Hitachi. Toshiba chose to continue to offer the ABWR design independently. This design had received generic regulatory approval from the US safety regulator, the Nuclear Regulatory Commission (NRC) for 15 years from $1997^{4}$. Toshiba applied to renew this approval in 2010, but in July 2016, the application was withdrawn because of the lack of potential US customers ${ }^{5}$. One utility, NRG, had said it would buy two ABWRs in 2009 for its South Texas prospect, but this project made little progress and is unlikely to go ahead.

Toshiba's main option is the Westinghouse AP1000 PWR, which in 2006 appeared close to completing regulatory review by the NRC, although this was only finally achieved in 2011. Four AP1000s were ordered for the US market, two each for the Summer and Vogtle sites and construction started on these in 2013/14 but a combination of serious cost overruns and delays, and the bankruptcy of Westinghouse led to the abandonment of the Summer project in 2017 with the Vogtle project also at risk of abandonment

The AP1000 was submitted to the UK safety regulator, Office of Nuclear Regulation (ONR), in 2007 in the Generic Design Assessment (GDA) process but the process was suspended in December 2011 due to the lack of UK customers. At that time, there were still 51 design issues to be resolved ${ }^{6}$. Subsequently, Toshiba bought a 60 per cent stake in a UK-based consortium, NuGen, which plans to build three AP1000s. The GDA process was re-opened in 2014 and was completed in $2017^{7}$. Toshiba sold its bankrupt Westinghouse nuclear division in 2018 and it is not clear whether it expects to continue to try to sell reactors. The NuGen project seems unlikely to proceed, at least using AP1000 technology. The Combustion Engineering capability gave Toshiba System $80+$ PWR technology, which had received regulatory approval from the NRC in 1997, while the ABB stake gave them a 50 per cent stake in a company, HTR, offering high temperature gas-cooled reactor technology, HTR-Modul. The System 80+ and HTR-Modul capabilities were not directly marketed but these technologies had already been licensed, the System $80+$ to Korea and HTR-Modul to South Africa and China.

4 For details of NRC reactor design reviews, see http://www.nrc.gov/reactors/new-reactors/ design-cert.html (Accessed March 1, 2016)

5 https://www.mynewsdesk.com/toshiba-global/pressreleases/toshiba-withdraws-application-to-u-s-nuclear-regulatory-commission-to-renew-abwr-design-certification-1462359 (Accessed July 15, 2016)

6 http://www.onr.org.uk/new-reactors/ap1000/index.htm (Accessed July 15, 2016)

7 http://www.onr.org.uk/new-reactors/ap1000/index.htm (Accessed September 2, 2018) 


\section{Hitachi}

The history of Hitachi in the nuclear business was intimately connected with that of GE and Toshiba until 2006. Under the reorganisation resulting from Toshiba's acquisition of the Westinghouse nuclear division, two new joint ventures were set up: GE-Hitachi, 80 per cent owned by GE which was to operate primarily in the USA and Hitachi-GE, 80 per cent owned by Hitachi, which was to operate in all other markets ${ }^{8}$. GE-Hitachi applied to renew the license for their version of the ABWR in 2010 despite it having no immediate US customer, but by February 2016, little progress appeared to have been made on this. The ESBWR did receive US regulatory approval in 2015. However, the prospects for sales of reactors in the USA, either of the ABWR or ESBWR designs, appear poor and GE-Hitachi is not considered further. Hitachi-GE purchased a UK-based consortium set up to build and operate nuclear power plants in Britain, Horizon, in 2012 for $\$ 1.2 \mathrm{bn}^{9}$. Horizon owns two sites at each of which it plans to build two ABWRs. The ABWR design was submitted to the UK safety regulator, ONR, for Generic Design Assessment in 2014 with expected completion of the review in $2018^{10}$. The Horizon projects can only proceed if Hitachi-GE finds a strong investor, either a utility or the UK government.

\section{Framatome}

Framatome achieved a dominant position in reactor supply for France in 1975 when its version of the PWR, licensed from Westinghouse, was chosen for the large programme of reactors that followed. By 1990, 58 PWRs had been sold to the French market. Framatome was initially privately owned but in 1975, the Commisariat Energie Atomique, the French national nuclear R\&D organisation took a 30 per cent stake, expanding to 34 per cent in 1982 and in 1984, when the parent of the other shareholder, Creusot Loire went bankrupt, the government re-organised the shareholding with CEA taking 35 per cent, the large diversified French engineering company, CGE, taking 40 per cent and EDF with 10 per cent taking most of the rest.

Framatome had progressively moved away from the Westinghouse licensed design terminating its technology license with them in 1981 and the last four of the 58 reactors ordered were for a design designated $\mathrm{N} 4$, the first design that was claimed to be wholly French. However, the Chernobyl disaster led to a perceived need for greater safety and in 1992, a new design, the European Pressurised Water Reactor

8 An exception to this is GE-Hitachi's PRISM fast reactor design which is being marketed in export markets, for example, the UK. See http://gehitachiprism.com/ (Accessed July $22,2016)$

9 Associated Press 'Japan's Hitachi to buy Horizon Nuclear' October 30, 2012

10 http://www.onr.org.uk/new-reactors/uk-abwr/index.htm (Accessed March 1, 2016) 
(EPR) was announced developed by a joint venture of Framatome and Siemens, Nuclear Power International ${ }^{11}$. The aim was that the design would be licensable in both France and Germany. In 2000, Framatome (66 per cent) and Siemens (34 per cent) merged their nuclear businesses as the Areva NP part of the Areva group ${ }^{12}$. In January 2009, Siemens announced it would exercise its right to withdraw from the joint venture and this was completed in 2011.

The EPR was submitted to the UK's GDA process in 2007 and was given a design acceptance certificate, valid for 10 years in December $2012^{13}$. In 2008, Areva NP also submitted its EPR design to the US NRC for generic appraisal. However, in 2015 , with no US orders likely, it froze the process ${ }^{14}$.

The financial collapse of Areva led to it being split into its component parts, a reactor vendor division and a fuel cycle company. A majority stake in the reactor divisions was bought by the French utility, EDF, in 2018 and the company was renamed Framatome. By mid-2018, it was not clear what plans EDF had for Framatome.

\section{Rosatom}

Rosatom, the Russian national nuclear company, is a vast diversified company involved in every aspect of nuclear technology including fuel cycle activities, ownership and operation of reactors as well as reactor sales.

Russia was the first country in the world to operate a power reactor with the 6MW Obninsk reactor opened in 1954. Russia commercialised two types of reactor, the VVER, the Russian version of the PWR, and the RBMK, the design used at the Chernobyl site. The VVER has been built in two sizes, $440 \mathrm{MW}$ and 1000MW. For this analysis, we focus on the period after the 1986 Chernobyl disaster and we do not look at the RBMK which ceased to be an option for new orders after 1986. We focus particularly on the period from 2007 onwards when Russia began again for the first time since 1986 to market reactors in large numbers for Russia and for export. For an overview of Russia's nuclear history up to the Chernobyl disaster, see Schmid (2015) and IAEA (1997).

At the time of the Chernobyl disaster, Russia was building reactors in Russia, Ukraine, Lithuania Czechoslovakia, the German Democratic Republic (GDR), Poland, Bulgaria, Cuba and Hungary. Some of these were completed without interruption, such as Hungary and Lithuania, for some construction was halted for

11 Nuclear News 'Joint Franco-German design partly unveiled' August 1992

12 Nuclear Engineering International 'Framatome and Siemens to merge' February 2000

13 http://www.onr.org.uk/new-reactors/uk-epr/design-acceptance.htm (Accessed July 15 2016)

14 Nuclear News ‘Areva suspends work on U.S. EPR certification' April 2015 
a significant period but later restarted, such as Russia, Ukraine, Czech Republic, Slovak Republic while other programmes were abandoned, such as the GDR, Cuba and Poland. By that time, for the VVERs, Russia was concentrating on the 1000MW design, the V-320.

The first new activity of the Russian nuclear industry after Chernobyl was with the order in 1997 of two reactors using the AES-91 design for the Tianwan site in China ${ }^{15}$. This was followed by the order in 2002, after several years of negotiation, of two reactors using the AES-92 design for the Kudankulam site in India ${ }^{16}$. These reactors were essentially the V-320 design with additional safety systems, greater 'passive' safety and a core-catcher for the AES-91. The AES-91 was developed by the St Petersburg design studio of Rosatom, Saint-Petersburg Atomenergoproekt, while the AES-92 was developed by the Moscow Office, Moscow Atomenergoproekt ${ }^{17}$.

However, it was the announcement of a new design, AES-2006, in 2006 along with ambitious targets for new reactor orders for the Russian home market that saw a sudden change of gear for the Russian nuclear industry (Mukhatzhanova, 2007). Although this time there was a single designation, AES-2006, as with AES-91 and AES-92, there was a Moscow (V-392M) and a Saint-Petersburg (V-491) version with the first four orders, all for Russia, split between the two versions ${ }^{18}$. Forecasts of a steady flow of three orders a year for the home market were quickly proved wrong. Only one further order beyond the first four, on which construction started in 2008-10, was placed (in Kaliningrad in 2012) and this was effectively abandoned within a year of construction start. The focus switched to exports with an order for four reactors won with Turkey in 2010 and by 2017, Rosatom was claiming an export order book of about 30 reactors, although construction had started on only one project, in Belarus.

Some of these markets are for countries with no experience of commercial nuclear power plants, including Vietnam, Jordan, Bangladesh and Egypt and, historically, attempts to build nuclear plants in such countries often come to nothing. The potential orders for Finland and Hungary are most strategically important. The perception will be that safety regulation in EU countries is rigorous and if Russia

15 Xinhua News Agency 'Work on nuclear power station begins' October 20, 1999

16 Nuclear Engineering International 'Koodankulam deal signed' January 2002

17 For details of the history of the VVER design, see http://www.rosatom.ru/en/resources/ b6724a80447c36958cfface920d36ab1/brochure_the_vver_today.pdf(Accessed March 2, 2016)

18 For a detailed specification of the differences, see http://www.rosatom.ru/en/resources/ b6724a80447c36958cfface920d36ab1/brochure_the_vver_today.pdf(Accessed March 2, 2016). 
can satisfy the safety regulators in these countries, this will be seen as a strong endorsement of the design. In 2018, construction on the first reactors for orders to Turkey and Bangladesh belatedly started

In 2010, a new design, VVER-TOI (V-510), developed by the Moscow office was announced. It was claimed it would have lower design, construction, operation, maintenance and decommissioning costs, would be up to 38 per cent more efficient than the AES-2006 VVER design and would have a slightly higher rated capacity of $1300 \mathrm{MW}^{19}$. When it was announced, it was expected to be available for ordering in 2012, but it was not till 2018 that construction on the first unit began.

\section{China}

China has three nuclear reactor vendors but with very different backgrounds. China National Nuclear Corporation (CNNC) was the original company set up in the 1960s, China General Nuclear (CGN) ${ }^{20}$ set up in 1994 and State Power Investment Corporation (SPI) set up in $2007^{21}$.

\section{CNNC and CGN}

Because of their common technology roots with technology licensed from Framatome, it is logical to deal with CNNC and CGN together. CNNC has its roots in the Second Ministry of Machine Building, from which the China Ministry of Nuclear Industry was created and was renamed CNNC in 1988. It makes no secret of its military roots and its continued military connections and its web-site states $^{22}$ : 'Historically, CNNC successfully developed the atomic bomb, hydrogen bomb and nuclear submarines and built the first nuclear plant in the main land of China. CNNC is the main body of the national nuclear technology industry, the core of the national strategic nuclear deterrence and the main force of the national nuclear power development and nuclear power construction and shoulders the duel historical responsibilities for building of national defence force, increasing the value of state assets and developing the society.'

19 Nuclear Engineering International 'Atomenergoproekt on track to market VVER-TOI in 2013' February 2012

20 Until 2013, CGN was China Guangdong Nuclear (CGN).

21 The State Nuclear Power Technology Company was created in 2007 and merged with the smallest of the big four Chinese generation companies, China Power Investment Corporation (CPIC) to form the SPI

22 http://www.cnnc.com.cn/tabid/643/Default.aspx (Accessed December 18, 2015) 
It was in 1985 that construction work began on the first reactor for the Chinese market, a small (300MW) indigenous design of Pressurised Water Reactor (PWR) ${ }^{23}$ designed by the Shanghai Nuclear Engineering Research and Design Institute (SNERDI), established in 1970 and supplied by CNNC. Four reactors of this design were exported to Pakistan between 1985 and 2011, China's only export market to date. In 1987, construction started on the first large reactors (Daya Bay), two $1000 \mathrm{MW}$ units imported from the French vendor Framatome. However, despite it being the only Chinese reactor vendor, CNNC was not a major player in this project. The Chinese partners in Daya Bay, primarily Guangdong Electric Power Company were consolidated into a new state-owned company, China Guangdong Nuclear (CGN) ${ }^{24}$ in 1994. In 1992, CNNC signed a technology transfer agreement with Framatome for the technology ordered at Daya Bay, the M310. In 1995, CGN signed a similar agreement with Framatome ${ }^{25}$. In 2008, construction work in China took off with six reactors beginning construction (four from CGN and two from CNNC) all based on the imported M310 design, CNP-1000. In 2009 and 2010, ten more reactors of this design started construction.

The M310 design dates back to the 1960s, having been licensed by Framatome in the early 1970s from Westinghouse. The Chinese authorities had already acknowledged more modern designs were needed. Its plan was to select one of the advanced designs on offer from foreign vendors importing a few reactors initially but progressively transferring the technology to Chinese companies. Two designs were considered, the French EPR supplied by Framatome's successor company Areva and the AP1000 supplied by Westinghouse, which, by then was owned by Toshiba. The AP1000 was chosen in 2006 with four reactors ordered, reportedly because of greater willingness of Westinghouse to transfer technology. However, a year later, an order for two EPRs was placed with CGN partnering Areva and EDF for this project.

It became clear that the AP1000 and the EPR were too expensive in their existing form and all three vendors began work to develop advanced reactor designs, using the designs of their licensee as the basis. These designs would meet the requirements of European and US regulators and would be Chinese Intellectual Property. CNNC and CGN developed smaller reactor designs (1000MW) than the EPR (1600MW) based on the M310, ACPR-1000 and ACP-1000 respectively. Four reactors in China using the CGN ACPR-1000 design and two reactor exports to Pakistan using the

23 The PWR is the most widely used type of reactor worldwide accounting for about two thirds of the world's operating reactors

24 http://www.cgnpc.com.cn/n1500/index.html (Accessed December 15, 2015)

25 Nuclear Engineering International ‘Growth in China’ November 2001 
CNNC ACP-1000 design had started construction by 2018. However, in 2013, the Chinese government required CGN and CNNC to 'merge' these designs to create the Hualong One or HPR-1000 design. It appears that CGN and CNNC have their own versions of the HPR-1000 which may have more in common with ACPR-1000 and ACP-1000 than with each other. By 2016, CNNC had started construction of two reactors in China using their version of the HPR-1000 and CGN had started construction of one.

Following the Fukushima disaster in March 2011, there was a sharp reduction in ordering and from 2011-14, construction started on only six reactors, two using the old design based on M310, two imported from Russia and two ACPR-1000s. In 2015 six construction starts took place, three for the HPR-1000, two for the ACPR-1000 and one for the CNP-1000. However, by September 2018, there had been only one construction start in China since the beginning of 2016. It is not clear what has led to this new pause in construction starts. Possible factors include the slowdown of electricity demand growth, which has led to serious overcapacity in some regions, concerns about the new technologies and shortage of skills and technological capacities.

By 2013, CGN and CNNC were beginning to look to export markets and an order with CNNC was agreed with Pakistan for two ACPR-1000s ${ }^{26}$ (construction on the first unit started in August 2015 and the second in May 2016). The export markets are coordinated by the Chinese Atomic Energy Authority (CAEA) and the National Development and Reform Commission and the three Chinese vendors do not appear to compete in the same market. In December 2015, a CNNC/CGN joint venture company, the Hualong International, was announced to export Hualong One technology ${ }^{27}$. In May 2016, CGN and CNNC signed an agreement that they would not compete with each other in export markets ${ }^{28}$.

CNNC would focus outside Europe with South America, including Argentina (building one Canadian design reactor then an HPR-1000) and Africa, including Sudan, its most likely markets. CGN would focus on Europe where its best opportunities appear to be in UK and Romania (building a Canadian supplied reactor). The UK would be a particular prize for CGN bringing prestige that would enhance CGN's prospects in other markets.

26 Most reports now state the design is the HPR-1000.

27 Nucleonics Week 'CNNC and CGN set up joint venture to export Hualong One reactors' January 7, 2016

28 Nuclear Engineering International 'China's CGN and CNNC agree not to compete' July 2016, p 5 


\section{SPI}

The AP1000 was chosen in 2007 over the EPR with four reactors ordered and a new company created, State Nuclear Power Technology Company ${ }^{29}$ (SNPTC), which merged with a utility to form State Power Investment Corporation (SPI) in 2015, to indigenise the technology. SNERDI was made a subsidiary of SNPTC giving it experience and substance. SNPTC's advanced design was the CAP1400, a scaled up version of the AP1000. By September 2018, construction on the two CAP1400 units firmly planned had not begun despite press reports forecasting an imminent start. In May 2016, it was reported that the design was only complete enough for one year of construction work to be carried out and there was said to be discussion whether the CAP1400 should be for export only ${ }^{30}$. Whether China can credibly offer a design for export that has not been built for the home market is questionable. There are reports that China is delaying start of construction on a CAP1400 until the first AP1000 is operating successfully and the first units only went critical in mid-2018 ${ }^{31}$.

In November 2014, Turkey announced it was in exclusive talks with SPI and Toshiba/Westinghouse to buy four reactors, two using the Toshiba AP1000 design and two using the CAP1400 with construction start forecast for 2018/19. However, by 2016, it was reported that the talks were not going well and were no longer exclusive $^{32}$. At best, the timetable is likely to slip and at worst, not to go ahead. SPI is one of five vendors competing in South Africa for an order for 6-8 reactors but it did not appear to be a front-runner and in August 2018, South Africa effectively abandoned its nuclear programme.

\section{A comparison of the competitive positions of the vendors}

For this analysis (see Table 1), we look at the current design being offered by each of the vendors: for Westinghouse, this is the AP1000, for Framatome, the EPR, for Hitachi-GE the ABWR, for Rosatom the AES-2006, for CNNC and CGN the HPR-1000 and for SPI CAP1400.

29 http://www.snptc.com.cn/en/ (Accessed December 18, 2015)

30 Nuclear Intelligence Weekly 'Weekly Round-up' May 20, 2016, p 1

31 Nuclear Intelligence Weekly 'Nine Projects Top Priority List' May 6, 2016, p 5

32 Nuclear Intelligence Weekly 'Akkuyu’s Prospects Pull Past Sinop’ July 22, 2016, p 3-4. 


\section{Home market}

A strong home market provides a vendor with a market that may be less cost sensitive and competitive than export markets giving it a more assured flow of orders and a profitable base. An assured flow of orders will allow the build-up of a strong, efficient supply chain and reactor importers will see regulatory approval in the home market as a demonstration of the licensability of the design, especially where the home market has a long history of building and operating reactors and where the regulatory body is open and accountable.

On this criterion, the Chinese vendors appear strongest with the likelihood that all three vendors will receive at least two orders per year, although doubts about the role of the CAP1400 may weaken the position of SPI. Ten years ago, Russia and France were forecasting a strong market to replace existing reactors and to meet electricity demand growth. For France, the economics of life-extension appear far more attractive than new-build and there is little prospect of many orders being placed. Russia is still talking about new projects but these have been constantly delayed. Prospects for the Japanese home market appear for Hitachi and Toshiba appear poor with the priority likely to be getting existing plants back on line rather than trying to build new ones. Westinghouse is often seen as a US company because of its US base, but the prospects in the USA for new orders, particularly following the problems at the Summer and Vogtle projects also appear equally bleak there.

\section{Regulatory approval}

The USA and the UK are both carrying out rigorous generic reviews of designs to establish for all sites the licensability of the design, a process that has taken 5-10 years. Design approval means that for a period of 10 (UK) or 15 (USA) years the design is approved leaving only site-specific issues to be reviewed in any application to construct or operate a plant. The AP1000 has completed the US and the UK process. EPR has completed the UK process but the US process was abandoned in 2015 largely because there were no immediate prospects of reactor sales to the USA. The GE/Toshiba/Hitachi ABWR was licensed in the US in 1997 but this expired in 2012. Renewal was applied for independently by both GE-Hitachi and Toshiba but by 2016, little progress appeared to have been made and Toshiba effectively abandoned its renewal application. Hitachi-GE submitted their updated version of the ABWR to the UK authorities in 2014 and was completed in December 2017. The Russian regulatory process is opaque and documentation is not available so buyers would have to trust in the rigour of the Russian process. Equally, the Chinese process is not transparent. The reviews that do take place seem to take about a year, suggesting they are not in the same depth as the US/UK equivalent. 


\section{Experience with their current designs}

Only the ABWR has actual operating experience with four reactors completed in Japan, the first in 1992. These have not operated very little since the Fukushima disaster but up to that point, their lifetime load factor was poor, only about 60 per cent. Four further ABWRs have started construction, two in Japan and two in Taiwan but none of them were actively being built in 2016 and they are unlikely to be completed. The EPR has four reactors under construction (two in China and one each in Finland and France) and by 2016 these were $4-10$ years late and well over-budget. The two reactors under construction in China were started last but the first reactor in China went critical in June 2018. The eight AP1000s that started construction are also very late and over-budget. The Summer project was about 4 years late when it was abandoned and the Vogtle project is also at least 4 years late. The AP1000s nearest to completion are the four reactors under construction in China, the first two of which went critical in mid-2018. Six AES-2006s have started construction with the four in Russia are all at least four years late. The first two reactors were completed in 2017 and 2018. In July 2016, one of the reactor vessels for the Belarus project was dropped while it was being manoeuvred into position. Belarus has demanded that the vessel be replaced and Rosatom has agreed. It is not clear how far this will delay the project ${ }^{33}$. Two each of the CNNC and the CGN versions of HPR-1000 were under construction by September 2018. There is no construction experience yet with CAP1400.

\section{Government support}

The support of the vendor's national government is increasingly key for winning orders, particularly providing finance and coordinating other companies to participate. China appears to have particular advantages in this respect because of the strength of China's economy and its ownership of the vendors. These advantages remain unproven in export markets and if economic growth in China is not sustained, there may be less scope for China to support its vendors. The Russian government is also intimately connected with its vendor, Rosatom, and most of the export orders it claims are reliant on Russia providing the finance. However, international sanctions resulting from the Ukraine issues, the collapse of the oil price and the money spent by the Kremlin trying to defend the rouble mean the capacity of Russia to provide finance for exports must be in doubt. One of the main

33 TASS 'Rosatom to observe Minsk's demand for replacement of Belarus NPP reactor vessel - company’ August 12, 2016 
reasons given for delays completing nuclear power plants in Russia is lack of funds (Thomas, 2015).

Ironically, the Japanese government was in the process of setting up government mechanisms to support Japanese vendors Hitachi and Toshiba, including provision of loan guarantees in 2010 at the time of the Fukushima disaster. The Japanese government still seems determined to support nuclear power but it remains to be seen whether it can get the political support to do this and by 2018, Japanese vendors had won no orders with this government support and Toshiba's future as a reactor vendor was in doubt.

Areva claimed that it could supply sovereign loan guarantees for reactor exports ${ }^{34}$ for example to China and South Africa. It did provide $€ 610 \mathrm{~m}$ in loan guarantees for the Finnish Olkiluoto project in $2003^{35}$, but this project has gone badly and it may be that the guarantees will have to be paid. However, this sum, 20 per cent of the expected construction cost, would appear not to be adequate coverage for a project now and the expected cost of nuclear has increased markedly. For example, the expected cost of the two reactor Hinkley Point project is about $£ 30$ bn and this is expected to require 70 per cent coverage by loan guarantees for the deal to be viable. This would result in guarantees worth about $£ 21 \mathrm{bn}$. Whether the French government is willing to guarantee such sums must be in doubt. Whether Framatome, under the control of EDF, would continue to try to sell reactors was not clear by mid-2018.

\section{Vendor's financial position}

The decline of markets for reactors has left several of the vendors in financial difficulties. Most serious of these are the collapses of Areva and Westinghouse. In March 2015, Areva announced annual losses of $€ 4$.8bn, the fifth consecutive year of losses ${ }^{36}$. The public stake in Areva had continued to increase to around 87 per cent by then. It became clear that the company could not continue in its existing state and the French government launched a rescue attempt. The company was split into two main parts, the fuel cycle business, Areva NC, renamed Orano, and the reactor vendor and servicing business, Areva NP, renamed Framatome. EDF, itself 83 per cent state-owned, was required to take over up to 80 per cent of Areva NP for about $€ 2 \mathrm{bn}$. The plan is that EDF would sell up to a 29 per cent stake to a

34 Nucleonics Week 'French export credit agency to insure loans for Cgnpc, Eskom' August 21, 2008

35 Nucleonics Week 'European 'green power' generators challenge EPR's competitiveness' December 16, 2004

36 http://www.areva.com/finance/liblocal/docs/doc-ref-2014/DDR_EN_310315.pdf (Accessed March 1, 2016) 
third party leaving it with a 51 per cent stake. In July 2016, Mitsubishi and EDF signed a deal increasing cooperation and in 2017, Mitsubishi took a 19.5 per cent stake in Framatome ${ }^{37}$.

The French government had to recapitalise Areva with about $€ 4$ bn of public mone $^{38}$ and it also had to assume liabilities for failings with existing orders, for example, the cost overrun at Olkiluoto.

In July 2015, a report by an independent panel of accountants and lawyers from within the company showed that Toshiba had been overstating its profits for seven years. This led to mass resignations at board level including the $\mathrm{CEO}^{39}$. This resulted in all the credit rating agencies reducing Toshiba's credit rating and in December 2015 both Standard \& Poors and Moody's reduced the rating to 'junk' (non-investment grade $)^{40}$. In May 2016, Toshiba wrote down the value of the Westinghouse nuclear business, which it had acquired in 2006 for $\$ 5.4 \mathrm{bn}$ by $\$ 2.4 \mathrm{bn}^{41}$. In May 2016, Toshiba announced its largest ever loss of Yen460bn (\$4.2bn) for FY $2015^{42}$ and in March 2017, Westinghouse declared bankruptcy. Toshiba effectively cut the Westinghouse division adrift and it was sold to the Canadian company, Brookfield Business Partners. By mid-2018, it was not clear whether Westinghouse's new owners would pursue new reactor orders or whether it would concentrate on the less risky and more lucrative reactor servicing and maintenance market. By mid2018, it was not clear whether Toshiba would attempt to rebuild a reactor vendor division based on its BWR capability.

The Hitachi group does not appear to be in serious difficulties although its nuclear division has not sold a reactor for nearly 20 years. The three Chinese vendors appear profitable. It is difficult to determine the strength of the Rosatom group but the weakness of the Russian economy in general is likely to restrict its scope.

37 Nuclear Intelligence Weekly ‘EDF’s Balancing Act Between MHI and CGN’ July 8, 2016, $\mathrm{p} 4$

38 Nucleonics Week 'EDF taking over Areva reactor business: government' June 4, 2015

39 Japan Times 'Heads roll at Toshiba as scandal claims top brass' July 22, 2015

40 Agence France Presse 'Moody's, S\&P cut scandal-hit Toshiba's credit rating to junk' December 22, 2015

41 Nuclear Intelligence Weekly 'Toshiba Warns of \$2.4 Billion Westinghouse Impairment' April 29, 2016

42 http://www.toshiba.co.jp/about/ir/en/pr/pdf/tpr2015q4e_ca.pdf(Accessed July 20, 2016) 


\section{Conclusions}

The nuclear reactor supply industry, once seen as an essential component of diversified companies with an electrical engineering capability, is now seen in Europe and USA as a risky niche business for specialist companies. In Japan, the capability is still in the hands of national champion companies but their commitment to the sector must be in doubt following the Fukushima disaster.

If the nuclear reactor vendor business is to have a future, it appears increasingly likely that it will be driven by Russia and China. For both countries, their nuclear industry appears to be part of national policy to expand their political and economic influence. However, neither of these has significant experience in developed countries with well-resourced critical customers, with experienced, independent safety regulators and with well-developed public participation channels. For some developing country markets that have less capability to be critical customers, this may not be a restriction, but such markets are usually of limited scale, require significant financial support and, historically, nuclear programmes in such countries often do not materialise.

The volume of nuclear orders being placed for China are often seen as China 'going nuclear' but the reality is that nuclear only makes up about 3 per cent of its electricity supplies and because of its rapid electricity demand growth, even if its most ambitious plans are realised, it will still get less than 10 per cent of its electricity from nuclear power. If these plans are to be realised, China needs to get over a major hurdle of siting plants inland rather than on the coast where all the existing plants are. There is considerable resistance to inland siting (King and Ramana, 2015) and if this is not overcome, the scope for further nuclear capacity will be heavily restricted. So while the world nuclear industry may well need China for its survival, China does not necessarily need nuclear power. So if exports of nuclear plants are not bringing it the political influence and economic influence it is hoping for, it may not pursue the export market, even if it does continue to build in China.

For Russia, the dynamics are rather different. Electricity demand in Russia is falling, and, in the short-term, it probably lacks the financial resources and the supply chain to build many reactors either for export or the home market. Its economy is nowhere near as flexible and competitive as China's so it cannot as easily as China switch the focus of its export efforts to other sectors.

It is hard to see the vendors from Japan and Europe - Hitachi-GE, Toshiba and Framatome - being competitive in nuclear export markets. Their technologies are problematic, they lack the comprehensive government backing that Russia and China give, and their home markets are minimal. The question then becomes do they need to sell new reactors to survive and perhaps profit. From 1991, when it 
started building the last completed reactor in France, Framatome/Areva has started building only four reactors, two in China, and one each in France and Finland. These orders have been highly problematic are unlikely to be profitable and have seriously damaged their reputation. The flow of work servicing and providing replacement parts for operating plants is much more predictable and probably more profitable. With utilities under more financial pressure than in the past, this work is perhaps less profitable than it was in the past and the original vendor is no longer so sure of getting the servicing work, but it still appears a better route than very risky new reactor projects. With about 160 reactors in USA and France beginning to reach the end of their design life and with their owners generally anxious to run them a further 20 years or more, this appears a market that would provide a continued flow of work for Hitachi-GE, Toshiba and Framatome. It would also give them the opportunity to think afresh on new reactor designs, taking into account the lessons from Fukushima, which are only now beginning to emerge.

\section{References}

IAEA, 1997. Performance analysis of WWER-440/230 nuclear power plants, IAEA-TECDOC-922, Vienna. http://www-pub.iaea.org/books/IAEABooks/5573/Performance-Analysis-of-WWER-440-230-Nuclear-Power-Plants (Accessed March 3, 2016)

Mukhatzhanova, G., 2007. Russian Nuclear Industry Reforms: Consolidation and Expansion, Centre for Non-Proliferation Studies, Monterey. http://www.nonproliferation.org/russian-nuclear-industry-reforms-consolidation-and-expansion/ (Accessed March 3, 2016)

Schmid, S., 2015. Producing Power: The pre-Chernobyl history of the Soviet nuclear industry, MIT Press.

King, A. \& Ramana, M.V., 2015, The China Syndrome? Nuclear Power Growth and Safety After Fukushima. Asian Perspective: October-December 2015, Vol. 39, No. 4, pp. 607-636.

Thomas, S., 2015. Nuclear construction problems, PSIRU, Greenwich http://www.psiru.org/ reports/nuclear-construction-problems (Accessed March 10, 2016) 
Tab. 1 A Comparison of the Competitive Position of the Major Nuclear Reactor Vendors

\begin{tabular}{|c|c|c|c|c|c|c|c|}
\hline 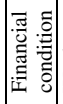 & 节 & 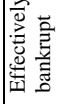 & ơ & ठै & ठै & ö & O \\
\hline 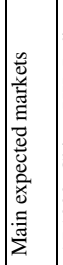 & 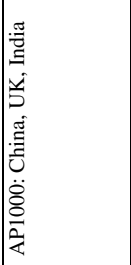 & 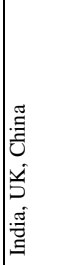 & 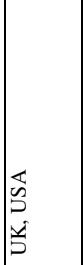 & 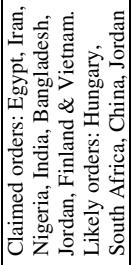 & 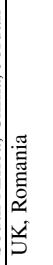 & 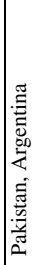 & 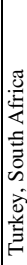 \\
\hline 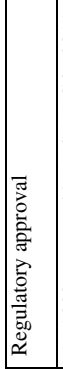 & 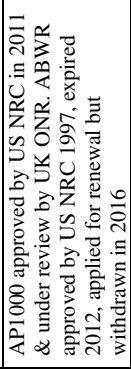 & 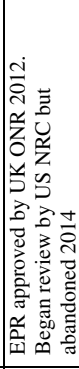 & 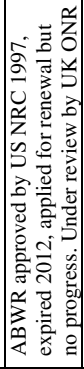 & 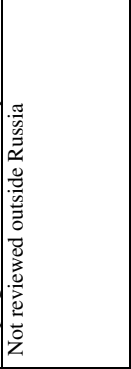 & 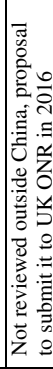 & 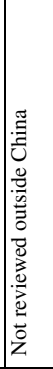 & 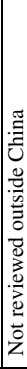 \\
\hline 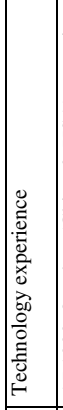 & 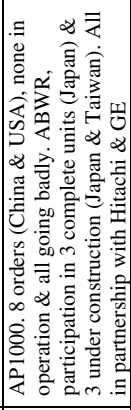 & 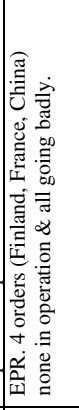 & 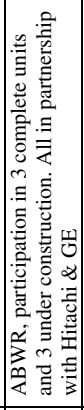 & 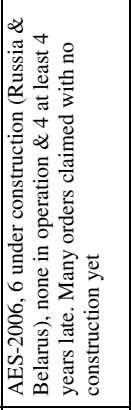 & 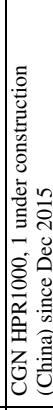 & 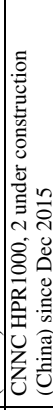 & 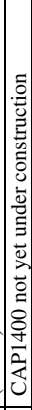 \\
\hline 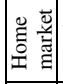 & 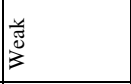 & 袍 & 裉 & 栚 & 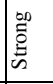 & 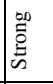 & 嵒 \\
\hline 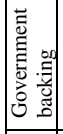 & 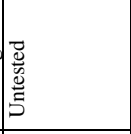 & 总 & 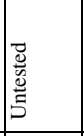 & 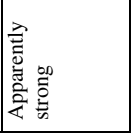 & $\begin{array}{l}00 \\
\tilde{\Xi} \\
\vdots \\
\omega\end{array}$ & 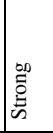 & \\
\hline$\frac{\vec{g}}{0}$ & 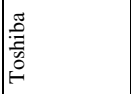 & 产 & | & 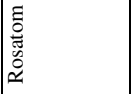 & Uु & 須 & \\
\hline
\end{tabular}


Open Access This chapter is licensed under the terms of the Creative Commons Attribution 4.0 International License (http://creativecommons.org/licenses/by/4.0/), which permits use, sharing, adaptation, distribution and reproduction in any medium or format, as long as you give appropriate credit to the original author(s) and the source, provide a link to the Creative Commons license and indicate if changes were made.

The images or other third party material in this chapter are included in the chapter's Creative Commons license, unless indicated otherwise in a credit line to the material. If material is not included in the chapter's Creative Commons license and your intended use is not permitted by statutory regulation or exceeds the permitted use, you will need to obtain permission directly from the copyright holder.

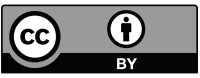

